DOI 10.7764/rcia.v45i2.1808

\title{
Morphological characterization of sweet chestnut fruits from forest plantations in central Chile
}

\author{
Susana Benedetti ${ }^{1}$, Francisco Balocchi ${ }^{2}$, Marta Gonzalez ${ }^{1}$, and Pablo Garcia- \\ Chevesich $^{3,4}$ \\ ${ }^{1}$ Forest Institute. Av. Sucre 2397, Santiago, Chile \\ ${ }^{2}$ Bioforest SA. Camino a Coronel s/n km 15, Coronel, Chile. \\ ${ }^{3}$ University of Chile, Faculty of Forest Sciences and Nature Conservancy. Avenida Santa Rosa 11315, \\ Santiago, Chile. \\ ${ }^{4}$ University of Arizona, Department of Agricultural and Biosystems Engineering. 1177 E. 4th Street, Shantz \\ Building, Tucson, AZ, USA.
}

\begin{abstract}
S. Benedetti, F. Balocchi, M. Gonzalez, and P. Garcia-Chevesich. Morphological characterization of sweet chestnut fruits from forest plantations in central Chile. 2018. Cien. Inv. Agr. 45(2): 138-146. The sweet chestnut (Castanea sativa Mill.) is one of the most important starchy foods worldwide due to its low fat content and high nutritional value. This study is the first analysis of the sweet chestnut fruit in forest plantations where the morphological properties are characterized, in terms of caliber, size, shape, and internal cracking, damage, and cavities. The study was based in three sites in Chile, Los Rios Region $\left(39^{\circ} \mathrm{S}\right)$, where most of the forest chestnut plantations are located. Scott and Knott test of variance and contingency tables were used as statistical methods for site comparisons. In general, no significant differences in size were found among sites. Moreover, the Chilean forest sweet chestnut can be defined as a small-caliber fruit with slight internal cracking and internal damage and almost no cavities. Therefore, due to its morphological characteristic (especially caliber), it has the potential to be used for secondary food products.
\end{abstract}

Keywords: Castanea sativa, fruit size and shape, Los Rios region, Scott and Knott.

\section{Introduction}

The European chestnut (or sweet chestnut, Castanea sativa Mill.) was introduced in Chile in the early 1800s (Grau, 2003). Its current distribution within the Chilean territory ranges from $34^{\circ} \mathrm{S}$ to $41^{\circ} \mathrm{S}$ latitudes (Grau and France, 1998; Joublan et al.,
2004). Originally from the northern hemisphere (mostly Europe and Asia) (Pereira-Lorenzo and Ramos-Cabrera, 2004), its fruit, the "sweet chestnut", is one of the most important nuts worldwide (Kan et al., 2017) due to its combination of high carbohydrate contents and low protein and fat contents (Saavedra, 1981; Dinis et al., 2008).

This species is mainly found in central Chile as fruit orchards covering a total estimated area of 339 hectares (Instituto Nacional de Estadística
Received May 31, 2017. Accepted Jul 30, 2018.

Corresponding author: francisco.balocchi@arauco.cl 
[INE], 2007), distributed over the Andes foothills. In contrast, only a few forest plantations can be found, ranging from 1 to 30 hectares, in the south of Chile between Los Rios and Los Lagos Region $\left(39^{\circ}-41^{\circ} \mathrm{S}\right.$ latitudes). The relevance of this study is that the forest plantation scope is wood production, where the trees are planted at a high density $(3 \times 3$ meters $)$ with no fruit varieties. While the production cycle is between 30 to 35 years, it was important to analyze the quality and potential of its fruit as a commercial option for plantation owners until wood harvest. Additionally, this species is especially important in Chile because it does not have relevant diseases attacking trees and fruits (Joublan et al., 2004).

Many studies in Europe have focused on the morphology of this fruit from natural forest conditions. Mujić et al. (2010), for example, described sweet chestnuts in Bosnia and Herzegovina, finding the smallest chestnuts within the Mediterranean area of Europe. On the other hand, Ertan (2007) studied morphological, pathological, and biochemical specs of the sweet chestnut in Turkey, where a large interaction between genotype/year was found. Similarly, Poljak et al. (2012) characterized the Croatian sweet chestnut fruit's morphology, finding significant differences between trees and populations in the fruit's morphology, especially fruit weight. Serdar and Soylu (1998) selected Turkckeysh chestnut types with best nut qualities such as size, color, and thickness, whereas Solar et al. (1998) in Slovenia characterized seven preselected chestnut fruit types, identifying the three best genotypes in this area (marron type) according to their number of fruits per bur, size, number of fruits per kilo, shape, cavities, episperm penetration, stripes, and sweetness. Finally, in a Croatian study, Poljak et al. (2016) characterized the quality and productivity of seven Lovran Marron morphological chestnut fruits, defining them as "attractive".

Despite the above, little is known about the morphology of sweet chestnut fruits from forest plantations in Chile, and just a handful of studies have focused on this interesting fruit.
Grau (2003), for example, studied 12 European fruit cultivars from Italy, France, and Japan using morphological fruit parameters and found a marron-type fruit. However, this study was done in fruit from chestnut orchards and not from forest plantations, as in the present study. Additionally, Benedetti et al. (2012) focused on germination and physical characteristics of chestnut from two forest plantations in Los Rios region, finding no significant differences between them. Considering the above statements and the lack of knowledge in this particular area, the objective of this study was to characterize the morphology of fruits from Chilean sweet chestnuts from forest plantations.

\section{Material and methods}

\section{Study site}

The study site was located in Los Rios region, where the most relevant concentration of forest chestnut plantations is found. Three sites (Figure 1) with similar characteristics were selected: Las Minas, 39 55'16.89" South latitude, $73^{\circ} 13^{\prime} 54.9^{\prime \prime}$ South longitude; Pillo Pillo, 39 $52^{\prime} 27.41^{\prime \prime}$ South latitude, $73^{\circ} 06^{\prime} 59.48^{\prime \prime}$ South longitude; and Pumillahue, 39³9'10.52" South latitude, $72^{\circ} 46^{\prime} 30^{\prime \prime}$ South longitude. All are properties of "Forestal Tornagaleones", a Chilean private forestry company. The plantation density was $3 \times 3$ meters, and trees were planted in 1978, 1980, and 1982, respectively.

Two sites were located along Chile's coastal range, Las Minas and Pillo-Pillo, and the third, Pumillahue, was in the central valley, with altitudes of 58.44, and 155 meters above sea level respectively. In general, the three sites have similar climate characteristics, with a mean annual temperature between $10.5^{\circ} \mathrm{C}$ and $16^{\circ} \mathrm{C}$, maximum annual temperature ranges from $21.4^{\circ} \mathrm{C}$ to $22.7{ }^{\circ} \mathrm{C}$, and minimum temperature between $3.1^{\circ} \mathrm{C}$ and $4.7^{\circ} \mathrm{C}$. Finally, mean annual rainfall is between $1600 \mathrm{~mm}$ and $2300 \mathrm{~mm}$ (Centro de Información de Recursos Naturales [CIREN], n.d.). 


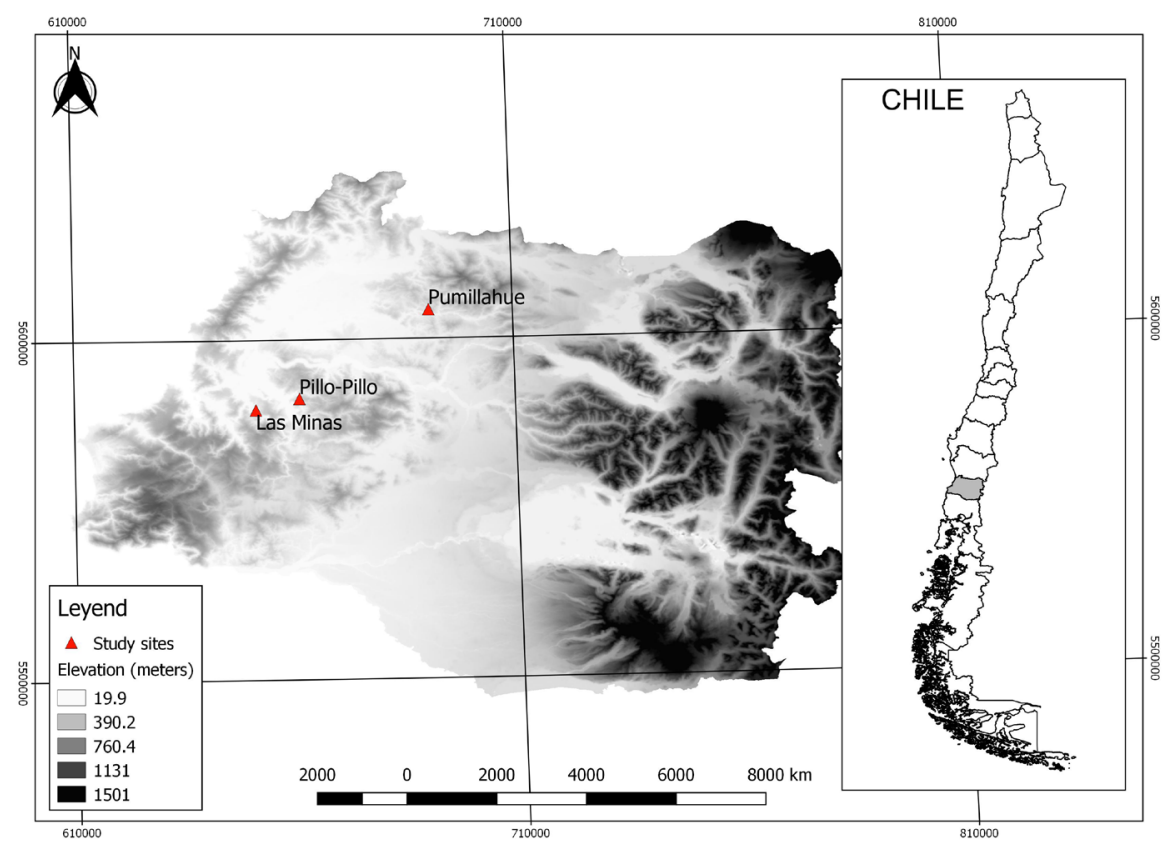

Figure 1. Location of the three study sites within Los Rios region and its location within Chile (gray).

In terms of soil properties, the three sites have similar conditions, characterized for being "good" soil conditions for the species: deep, light, well-drained soils, with loamy textures, and the presence of organic and litter layers (Benedetti and Saavedra, 2007). All climate and edaphic values were located within the Medel's parameter determination (Medel, 1986) for chestnut production in Chile.

\section{Sampling procedure}

To evaluate the fruit caliber a random statistic design was applied with ten chestnut fruits samples from each site, during harvest season in April 2008. Each fruit sample was one kilogram, weighed in the field and then in the laboratory, for validation purposes. To analyze the other morphological parameters considered in this study (i.e., internal cracking and internal damage, a random subsample of 30 fruits was selected, from each of the ten one-kilogram samples per site).

\section{Morphological parameters analysis}

Two morphological parameters (size and shape) were used for chestnut characterization. Each parameter was described according to several variables (Bolvanský and Mendel, 2001; Grau, 2003; Martín et al., 2008; Dinis et al., 2008). The variable "size" was evaluated based on caliber (number of fruits $/ \mathrm{kg}$ ), length (mm), width (mm),

Table 1. Definition of each additional quality parameters.

\begin{tabular}{lcccc}
\hline Parameter & 0 & 1 & 2 & 3 \\
\hline Cracking & $\begin{array}{c}\text { Without presence } \\
\text { of testa }\end{array}$ & $\begin{array}{c}\text { Slight presence } \\
\text { of testa }\end{array}$ & $\begin{array}{c}\text { Medium presence } \\
\text { of testa }\end{array}$ & Full fruit partition \\
Internal damage & No damage & Slight damage & Medium damage & Severe damage \\
Cavity & No cavity & Slight cavity & $50 \%$ cavity & Severe cavity \\
\hline
\end{tabular}


and thickness (mm). In relation to "shape", two indices were used: "R1" (ratio between fruit width and fruit length) and "R2" (ratio between fruit thickness and fruit length). Additionally, the quality of the fruit (in terms of percentage) was evaluated based on the fruit's internal cracking, internal damage, and the presence of cavities as shown in Table 1. Internal damage, expressed in percent (or number of damaged fruits over 100 fruits per site), referred to the presence of fungi or any other internal alterations. A contingency table was built in order to compare categorized data. A binary value was assigned in terms of the presence or not of fruit damage (i.e., "1" in presence of damage and " 0 " otherwise).

Later and to avoid the overlapping process of some test of variance (e.g., Tukey, 1949), the Scott and Knott cluster analysis (Scott and Knott, 1974) was performed to evaluate significant differences ( $\mathrm{p}$ value $<0.05$ ) between parameters on each analyzed site (SK test hereafter). To do this analysis, the ScottKnott R package was used.

\section{Results and discussion}

\section{Caliber and size parameters}

The number of fruits per kilogram ( $\mathrm{f} \mathrm{kg}^{-1}$ ), or caliber, was significantly different among all sites (Table 2). Pumillahue had the highest mean fruit/ kilogram $\left(135.6 \mathrm{f} \mathrm{kg}^{-1}\right)$, sharing the same standard deviation as Las Minas, the latter having the lowest mean fruit/kilogram (106 $\left.\mathrm{f} \mathrm{kg}^{-1}\right)$. In contrast, Pillo-Pillo's mean fruit/kilogram was between those from the two other sites $\left(110.8 \mathrm{f} \mathrm{kg}^{-1}\right)$, but with a lower standard deviation. These results were validated with the analysis of variance was performed, which found significant differences among all sites for this parameter. The above results could be derived from the different climate conditions in the Pumillahue sites, being the only sites with one dry month, less annual precipitation, and more below-freezing days.
Based on results from Ayfer et al. (1977), caliber values of the Chilean sweet chestnut fruits from forest plantations can be classified as "small", similar to the Asturian chestnuts (Díaz-Hernández et al., 2003). Regarding Las Minas sites, its caliber value is similar to the Gallega's chestnuts, with $106 \mathrm{f} \mathrm{kg}^{-1}$ (Pereira-Lorenzo and Fernández-López, 1997a, b), and those by Pereira et al. (2005) in Asturias, Spain, where $80 \%$ of their sites had $100 \mathrm{f} \mathrm{kg}^{-1}$.

This small caliber condition obtained in this study, is confirmed when we compared it to Grau (2003) studies about the marron-type fruits introduced in Chile from Italy, France, and Japan, obtaining calibers between 67 and $99 \mathrm{f} \mathrm{kg}^{-1}$ from high-quality trees, and similar to the results of Noria's (2000) study on chestnut orchards in the Andes foothills of Biobio region whose measured mean caliber values were between 52 and $59 \mathrm{f} \mathrm{kg}^{-1}$.

In general, the size parameters present a similar behavior in all sites (Table 2). In fact, it is possible to fit the data into a normal distribution. However, the intervariability in Las Minas for these parameters, within three sites, seems higher. This variability can be related to geographic location differences, especially with the coastal or marine influences (sites near the Pacific Ocean), which usually alleviate summer drought (Gondard et al., 2001) and the possibly higher soil moisture content in this region. It is important to point out that length, width, and thickness are some of the most important fruit characteristics defining the commercial value of sweet chestnut (Soylu and Ayfer, 1993).

Mean length value was nearly $27 \mathrm{~mm}$, while the variance analysis suggests a slight difference in Pillo-Pillo sites, with the highest value among all sites $(2 \mathrm{~mm})$. However, Las Minas sites had a higher standard deviation, which in general is higher than the values obtained in other studies (e.g., Mujić et al., 2010), and this might be related to the small sample size. 
Table 2. Descriptive statistics for all sites: caliber, size, and shape parameters (different letters in the same column mean statistically significant differences in SK test, p-value $<0.05)$.

\begin{tabular}{llcccccc}
\hline Sites & & Caliber $\left(\mathrm{f} \mathrm{kg}^{-1}\right)$ & Length $(\mathrm{mm})$ & Width $(\mathrm{mm})$ & Thickness $(\mathrm{mm})$ & $\mathrm{R} 1$ & $\mathrm{R} 2$ \\
\hline Las Minas & Mean & $106.00 \mathrm{~b}$ & $27.13 \mathrm{~b}$ & $29.43 \mathrm{a}$ & $16.68 \mathrm{~b}$ & $109.10 \mathrm{a}$ & $61.64 \mathrm{a}$ \\
& Std. Deviation & 12.8 & 3.3 & 3.7 & 3.3 & 12.3 & 11.1 \\
& Minimum & 82.0 & 17.7 & 17.9 & 6.8 & 72.6 & 33.3 \\
& Maximum & 127.0 & 35.1 & 38.7 & 29.2 & 135.8 & 109.2 \\
Pillo-Pillo & Mean & $110.8 \mathrm{~b}$ & $28.6 \mathrm{a}$ & $29.4 \mathrm{a}$ & $17.5 \mathrm{a}$ & $103.0 \mathrm{~b}$ & $61.4 \mathrm{a}$ \\
& Std. Deviation & 8.0 & 2.6 & 3.3 & 2.4 & 10.2 & 8.4 \\
& Minimum & 99.0 & 21.7 & 20.9 & 10.7 & 77.2 & 42.1 \\
& Maximum & 125.0 & 36.7 & 41.05 & 28.23 & 128.42 & 98.98 \\
Pumillahue & Mean & $135.6 \mathrm{a}$ & $26.8 \mathrm{~b}$ & $28.9 \mathrm{a}$ & $16.1 \mathrm{c}$ & $108.4 \mathrm{a}$ & $60.1 \mathrm{a}$ \\
& Std. Deviation & 16.4 & 2.6 & 3.7 & 2.8 & 12.4 & 9.4
\end{tabular}

In terms of width, the homogeneity of these values matches with the variance analysis from the SK test (Table 2). In fact, the width parameter was the only one with no significant differences among sites. Even though this parameter got the highest variability compared to all others, it should be noted that these chestnuts are more rounded (similar height and width). The mean thickness values were approximately $17 \mathrm{~mm}$. All sites had similar mean values $(16.68,17.48$, and $16.07 \mathrm{~mm}$ for Las Minas, Pillo Pillo, Pumillahue, respectively), with higher data dispersion in Las Minas, suggesting that the thickness parameter is more vulnerable to little changes in its value, because the magnitude of the value itself was significantly lower. This, in part, could explain why SK test showed significant differences among all sites (Table 2).

In regards to mean values for size parameters (length, width, and thickness (Table 2)), the results coincide with those by Dinis et al. (2008) from Murca in Trás-os-Montes and Alto Douro, Portugal, with 27.4, 25.65, and $14.51 \mathrm{~mm}$ for length, width, and thickness, respectively. Additionally, these results agree with those by Martín et al. (2008), for the early variety in Andalucía.

\section{Shape parameters}

In relation to the shape parameters, the $\mathrm{R} 1 \mathrm{pa}-$ rameter (Table 2) appears to be similar among sites (103, 108, and 109 for Pillo-Pillo, Pumillahue, and Las Minas, respectively). However, the K variance test showed that only Las Minas and Pumillahue had similar values, which could mean that the two sites are from the same provenance. Additionally, standard deviation values showed high variability; a behavior that can be explained because R1 is calculated using length and width, this relationship assimilates both variances inside the parameter. These results match those by Dinis et al. (2008) for chestnuts from different areas in Trás-os-Montes and Alto Douro in Portugal. Pillo-Pillo sites had values similar to those obtained by Dinis et al. (2008) in Carrazedo de Montenegro (R1 of 103 and 102) and Murça location (R1 of 108).

In terms of the $\mathrm{R} 2$ parameter, the results showed no significant differences among sites, where mean values were 61, 60, and 62 for Pillo-Pillo, Pumillahue, and Las Minas, respectively. Within each site, Las Minas had greater data dispersion, 
which could be explained by having fruits wider than normal, but shorter in length. However, it should be mentioned that the $\mathrm{R} 2$ parameter was out of range (lower limit), because of a smaller width and larger length.

\section{Internal cracking, internal damage, and cavity}

In general, most of the fruit samples had no cracking (example on Figure 2) for all analyzed sites. According to Vieitez et al. (1996), the cracking is a fundamental parameter for fruit quality in
Italy and France. Specifically, no cracking (0 level, Table 3) is the only level that had a significant difference among sites. In fact, Las Minas had the highest percentage at this 0 level, but no significant differences were found on the other levels (1 to 3). These results could be related to the small sample size. A low frequency of cracking level 2 and 3 could be observed from the above Table 3, having values between $7 \%$ and $12 \%$ for level 2 and $3 \%$ and $5 \%$ for level 3 . These values are in concordance with the French standard for high chestnut quality, with a maximum value of 12\% (Grau, 2003; Vieitez et al., 1996).

Table 3. Mean subsample results for cracking and internal damage (different letters in the same row mean statistically significant differences in SK test, $\mathrm{p}$-value $<0.05$ ).

\begin{tabular}{lcccc}
\hline Sites & & Las Minas & Pillo Pillo & Pumillahue \\
\hline Cracking (\%) & 0 & $54 \mathrm{~b}$ & $70 \mathrm{a}$ & $66.3 \mathrm{a}$ \\
& 1 & $29 \mathrm{a}$ & $19.7 \mathrm{a}$ & $23.3 \mathrm{a}$ \\
& 2 & $12 \mathrm{a}$ & $7.3 \mathrm{a}$ & $7.3 \mathrm{a}$ \\
& 3 & $5.0 \mathrm{a}$ & $3.0 \mathrm{a}$ & $3.0 \mathrm{a}$ \\
Internal Damage (\%) & No damage & $96.3 \mathrm{a}$ & $97.8 \mathrm{a}$ & $97.0 \mathrm{a}$ \\
& Slight damage & $1.3 \mathrm{a}$ & $1.5 \mathrm{a}$ & $1.1 \mathrm{a}$ \\
& Medium damage & $2.3 \mathrm{a}$ & $0.4 \mathrm{a}$ & $1.1 \mathrm{a}$ \\
& Severe damage & $0.0 \mathrm{a}$ & $0.4 \mathrm{a}$ & $0.7 \mathrm{a}$ \\
\hline
\end{tabular}

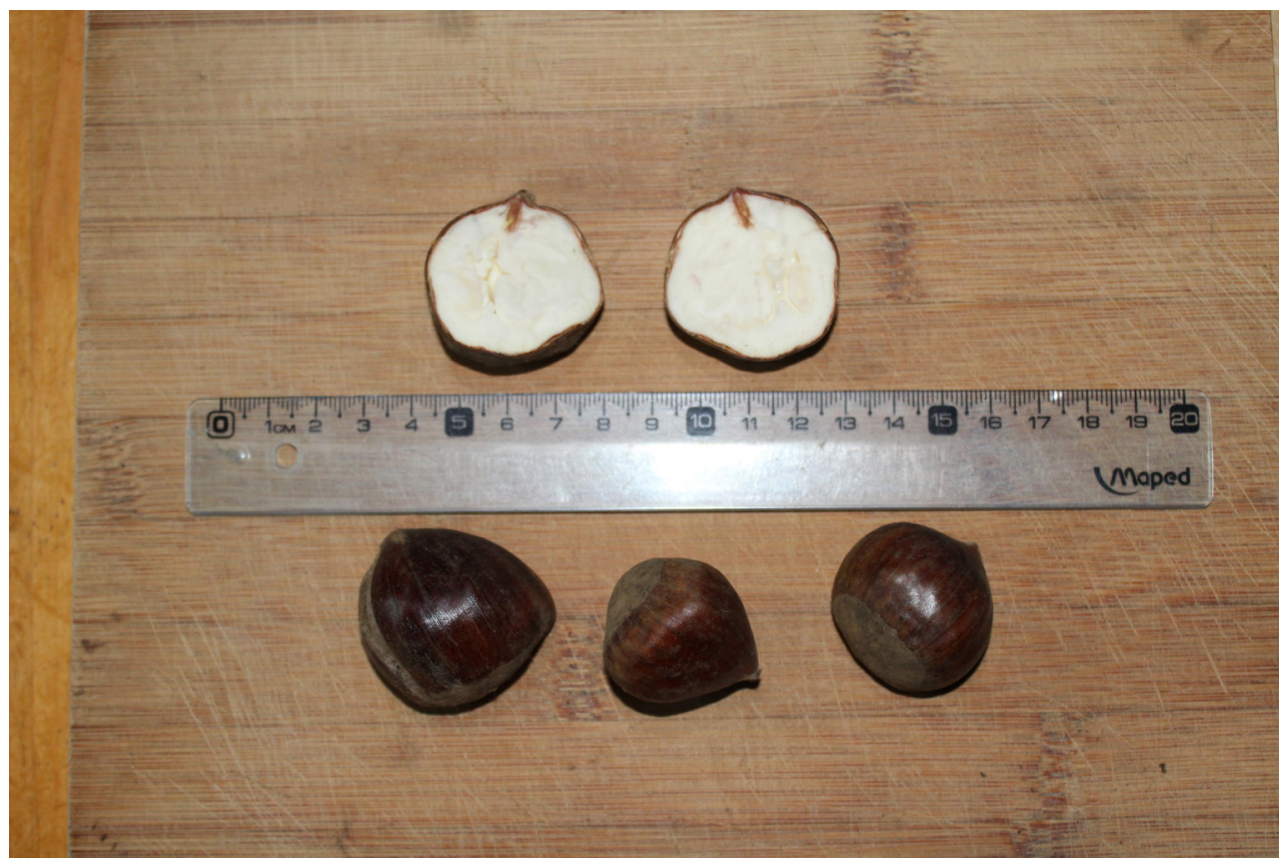

Figure 2. Example of no cracking, no internal damage, and no cavity. Subsample from the Las Minas site. 
For the fruit's internal damage, no significant differences among sites were found (Table 3), for the mean value per site, and all sites showed a high percent of nondamaged fruits (Table 4, $97.03 \%$ mean value).

The "cavity" parameter indicated almost no cavities on all sites. In fact, just a few fruits per sample had signs of cavities or external damage. For the 900 analyzed fruits, no external damage was found (just two fruits had internal cavities). For this reason, a detailed analysis was not needed.

Table 4. Contingency table for internal damage per sites.

\begin{tabular}{lll}
\hline Sites & No damage & Damage \\
\hline Las Minas & $286(95.3 \%)$ & $14(4.7 \%)$ \\
Pillo Pillo & $293(97.7 \%)$ & $7(2.3 \%)$ \\
Pumillahue & $292(97.3 \%)$ & $8(2.7 \%)$ \\
Total & $871(96.8 \%)$ & $29(3.2 \%)$ \\
\hline
\end{tabular}

The main conclusions are as follows. Even though the fruit caliber found was "small" (over 100 fruits per kilo), the sweet chestnut collected from three southern forest sites in Chile showed high quality fruits. The study results demonstrated a healthy fruit without partitions, internal damages, and cavities. Such fruit quality is similar to a marron-type chestnut. In general, comparing these results with European chestnut-related studies, Chilean fruits from forest plantations have similar values in shape (length, width, and thickness) and size (R1 and R2 parameters). Among sites, no significant differences were found, but some parameters such as width had high homogeneity, whereas the thickness parameter had high heterogeneity. Therefore, and due to its morphological values (especially caliber), the Chilean sweet chestnut fruits from forest plantations have the potential to be used for secondary products such as jam, mash chestnut, and flour. Moreover, a starch analysis is needed to be able to infer whether the Chilean sweet chestnut is a high-quality starchy fruit, as is the case for other chestnuts around the world.

\title{
Resumen
}

\begin{abstract}
S. Benedetti, F. Balocchi, M. Gonzalez, y P. Garcia-Chevesich. Caracterización morfológica de frutos de castaña provenientes de plantaciones forestales en Chile Central. 2018. Cien. Inv. Agr. 45(2): 138-146. El castaño (Castanea sativa Mill.) es uno de los frutos almidonados más importantes a nivel global dado su bajo contenido de grasas y alto valor nutricional. En el presente estudio, se caracterizó morfológicamente al fruto del castaño en términos de su calibre, su tamaño (i.e. largo, ancho y grosor), su forma (R1 como la relación entre el ancho sobre el largo y R2 como la relación entre el ancho y el grosor), y también su partición interna, el daño interno y su cavidad interna. El estudio se desarrolló sobre tres rodales ubicados en la Región de Los Rios, Chile $\left(39^{\circ} \mathrm{S}\right)$, lugar que concentra la mayor superficie de castaño en Chile. Los rodales se compararon estadísticamente usando la prueba de prueba de Scott y Knott, además de tablas de contingencia. En general, no se encontraron diferencias significativas entre rodales. Asimismo, el fruto del castaño estudiado puede ser definido como de calibre pequeño, con una baja partición y daño interno, además de casi nula cavidad. Por lo tanto y dado los resultados (especialmente el de calibre), el fruto analizado proveniente de rodales con fines madereros, tiene un alto potencial como productos secundario, como por ejemplo para mermelada, puré de castañas y harina.
\end{abstract}

Palabras claves: Castanea sativa, Región de Los Rios, Scott y Knott, tamaño y forma del fruto. 


\section{References}

Ayfer, M., A. Soylu, and G. Celebioglu. 1977. Selection of chestnut cultivars (Castanea sativa Mill.) in Marmara Region. In: Proc. Tubitak 4th Scien. Congr., Hortic. Sect., 84:123-132.

Benedetti, S., M. González, E. García, and I. Quiroz. 2012. An analysis of the physical and germination parameters of the sweet Chestnut (Castanea sativa). Cien. Inv. Agr. 39(1):185-192.

Benedetti, S., and J. Saavedra. 2007. Caracterización ambiental y productiva de rodales forestales de castaño en Chile. (In Spanish with English abstract.) Ciencia e Investigación Forestal (Chile) 13(1):111-123.

Bolvanský, M., and L. Mendel. 2001. Revised descriptor list for the evaluation of genetic resources of European chestnut (Castanea sativa Mill.). For Snow Landsc Res 76:439-444.

CIREN n.d. Fichas distritos agroclimáticos. Centro de Información de Recursos Naturales. Santiago, Chile.

Díaz-Hernández, M., A. Ramos-Cabrera, M. Ciordia-Ara, and S. Pereira-Lorenzo. 2003. Los cultivares de castaño en Asturias. In: Actas de Horticultura $\mathrm{N}^{\circ}$ 39. X Congreso Nacional De Ciencias Horticolas Pontevedra.

Dinis, L., J. Ferreira-Cardoso, M. Pimentel-Pereira, F. Peixoto, R. Costa, and J. Gomes-Laranjo. 2008. Study of biometric characteristics in judia (Castanea sativa Mill.) in eight different areas of Tras-os-Montes and Alto Douro. Proceeding of II Iberian Chestnut Congress. In: Acta Horticulturae 784 .

Ertan, E. 2007. Variability in leaf and fruit morphology and in fruit composition of chestnuts (Castanea sativa Mill.) in the Nazilli region of Turkey. Genetic Resources and Crop Evolution 54(4):691-699.

Gondard, H., F. Romane, M. Grandjanny, J. Li, and J. Aronson. 2001. Plant species diversity changes in abandoned chestnut (Castanea sativa) groves in southern France. Biodiversity and Conservation 10(2):189-207.

Grau, P. 2003. Introducción de cultivares de castaño (Castanea sativa Mil.), hibridos eurojaponeses
(Castanea crenata $\times$ Castanea sativa), y castaño japonés (Castanea crenata Siebold et Zucc) a Chile. (In Spanish with English abstract.) Agricultura Técnica 63(3):329-335.

Grau, P., and A. France. 1998. Chestnut production in Chile. Some steps toward its improvement. In: II International Symposium on Chestnut 494.

INE. 2007. VII Censo Nacional Agropecuario y Forestal. Instituto Nacional de Estadísticas. http://www.censoagropecuario.cl/index2.html (accessed 5 Feb. 2017).

Joublan, J., D. Ríos, and J. Montigaud. 2004. The competitive advantage of Chilean national fresh chestnut industry. In: III International Chestnut Congress 693.

Kan, L., Q. Zhao, J. Hu, Y. Wu, and J. Ouyang. 2017. Synthesis and physicochemical properties of carboxymethyl chestnut starch. Journal of Food Processing and Preservation 41(6):e13229.

Martín, M., J. Alvarez, and L. Martín. 2008. Caracterización del fruto en las principales variedades tradicionales de castaño de Andalucía. Actas II Congreso Forestal Iberoamericano de castaño. In: Acta Horticulturae 784, ISHS. p71-75

Medel, F. 1986. Requerimientos climáticos y edáficos para las especies frutales en el sur de Chile. AGRO SUR 14(1):48-56.

Mujić, I., V. Alibabić, J. Živković, S. Jahić, S. Jokić, Ž. Prgomet, and Z. Tuzlak. 2010. Morphological characteristics of chestnut Castanea sativa from the area of una-sana canton morfološke karakteristike pitomog kestena castanea sativa sa područja unsko-sanskog kantona. Journal of Central European Agriculture 11(2):185-190.

Noria, A. 2000. Algunas características físicas y morfológicas del fruto de castaño (Castanea sativa Mill) de la comuna de El Carmen. Dissertation, Universidad de Concepción.

Pereira-Lorenzo, S., and J. Fernández-López. 1997a. Los cultivares autóctonos de castaño (Castanea sativa) en Galicia. Monografía INIA 99. Madrid, España. 533 p.

Pereira-Lorenzo, S., and J. Fernández-Lopez. 1997b. Description of 80 cultivars and 36 clonal selection of chestnut from Northwestern Spain. Fruit varieties J51(1):13-27. 
Pereira-Lorenzo, S., and A. Ramos-Cabrer. 2004. Chestnut, an ancient crop with future. In: Production Practices and Quality Assessment of Food Crops. Springer Netherlands, Volume 1, p. 105-161.

Poljak, I., M. Idžojtić, M. Zebec, and N. Perković. 2012. The variability of European sweet chestnut (Castanea sativa Mill.) in the region of northwest Croatia according to morphology of fruits. Šumarski list, 136(9-10):479-488.

Poljak, I., N. Vahčić, M. Gačić, and M. Idžojtić. 2016. Morphological Characterization and Chemical Composition of Fruits of the Traditional Croatian Chestnut Variety 'Lovran Marron'. Food Technology and Biotechnology. 54(2):189-199.

Saavedra, O. 1981. Perspectiva para el desarrollo de frutales tipo nuez de Chile. Corporación de Fomento de la Producción CORFO. Gerencia de Desarrollo AA 81/45. Santiago, Chile. 302 p.
Scott, R., and M. Knott. 1974. A cluster analysis method for grouping mans in the analysis of variance. Biometrics 30(3):507-512.

Serdar, Ü., and A. Soylu. 1998. Selection of chestnuts (C. sativa Mill.). in Samsun vicinity. In: II International Symposium on Chestnut 494. p. 333-338.

Solar, A., F. Štampar, A. Podjavoršek, A. Šiftar, and I. Kodric. 1998. Characterisation of seven preselected chestnut fruit types from Slovene chestnut (Castanea sativa Mill.) population. In: II International Symposium on Chestnut 494. p. 95-100.

Soylu, A., and M. Ayfer. 1993. Floral biology and fruit set of some chestnut cultivars (Castanea sativa Mill.). In: Proc. Int. Congr. Chestnut, Spoleto, Italy, p. 125-130.

Tukey, J. 1949. Comparing individual means in the analysis of variance. Biometrics 5(2): 99-114.

Vieitez, E., M. Vieitez, and F. Vieitez. 1996. El Castaño. EDILESA, España. 